DOI 10.37882/2223-2982.2021.03-2.37

\title{
ТЕРМИНОСИСТЕМА «МАТЕРИАЛОВЕДЕНИЕ И ТЕХНОЛОГИИ МАТЕРИАЛОВ» В АНГЛИЙСКОМ И РУССКОМ ЯЗЫКАХ
}

\section{TERMINOLOGICAL SYSTEM “MATERIALS SCIENCE AND TECHNOLOGIES OF MATERIALS" IN THE ENGLISH AND RUSSIAN LANGUAGES}

\section{T. Stupina \\ O. Filonchik \\ V. Antolinovskaya}

Summary: The article presents a comparative analysis of technical terminology forming the terminological system «materials science and technologies of materials» in the English and Russian languages. Special aspects of terminological units functioning are considered. Derivation models and conceptual categories of terms are defined, issues of adequate translation of specialized words are engaged. Terms-borrowings and elements of metaphorical terminology generation in the studied subject area are highlighted, key sources of technical metaphors are identified.

Keywords: term, terminological system, terminological derivation, terminologisation, borrowings, translation, materials science, technologies of materials.
Ступина Татьяна Владимировна

К.культурологии, дочент, Сибирский федеральный университет (Красноярск) stupina_tv@mail.ru

Филончик Ольга Александровна

К.культурологии, дочент, Сибирский федеральный университет (Красноярск) oly-fill@yandex.ru

Антолиновская Вера Михайловна Старший преподаватель, Сибирский федеральный университет (Красноярск) antolinv@mail.ru

Аннотация: В статье проводится сравнительно-сопоставительный анализ технической терминологии, формирующей терминосистему «материаловедение и технологии материалов» в английском и русском языках. Рассматривается специфика функционирования терминологических единиц. Определяются деривационные модели и понятийные категории терминов, затрагиваются вопросы адекватного перевода специальной лексики. Отмечаются термины-заимствования и элементы метафорического терминопорождения в исследуемой предметной области, обозначаются приоритетные источники технических метафор.

Ключевые слова: термин, терминосистема, терминологическая деривация, терминологизация, заимствования, перевод, материаловедение, технологии материалов.
И зучение терминосистем и функционирование терминов в современной лингвистике рассматривается, как правило, с точки зрения сопоставительно-типологической и когнитивно-дискурсивной парадигм, учитывая разнообразный, специальный контекст: лингвистический; юридический; экологический; экономический; финансовый; физический; общественно-политический; архитектурный; авиационный; военно-технический; нанотехнологический; нефтяной; компьютерный; метеорологический; метрологический; метрический; медицинский (медсестринский, офтальмологический, стоматологический); спортивный; танцевальный; туристический и т.д.

В данной работе анализируются языковые единицы, полученные методом сплошной и частичной выборки из одноязычных и двуязычных справочников, энциклопедий, учебных пособий, терминологических словарей и специализированных научный журналов; номинирующие понятия материаловедения и технологий материалов и формирующие техническую терминологию в английском и русском языках.

Терминосистема «материаловедение и технологии материалов» характеризуется структурированной конфигурацией, распространенной количественной представленностью (включая неологизмы и нюансированные формулировки), а также высокой функциональной устойчивостью и активным развитием, находясь в прямой зависимости от современных тенденций в мире науки и техники.

Термины сферы материаловедения и технологий материалов в английском и русском языках образуют пять понятийных категорий:

1. «Материал» (aluminum - алюминий; cast iron чугун; ferrofluid - феррофлюид; glass - стекло; graphene - графен; nickel - никель; rubber - резина; steel - сталь; thermoset - реактопласт; tin - олоBo);

2. «Свойство» (brittleness - ломкость, хрупкость; elasticity - эластичность; hardness - твердость; plasticity - пластичность; specific strength - удельная прочность; stiffness - упругость; thermal conductivity - теплопроводность; toughness жесткость; waterproof - водонепроницаемость; wear resistance - износостойкость);

3. «Дефект» (bending - изгиб; broken bubble - кавер- 
на, раковина; crack - трещина; dimple - вмятина; entrapped slag - шлаковое включение; porosityпористость; rupture- разрыв; rust - ржавчина; shear - сдвиг; torsion - кручение);

4. «Способ обработки/изготовления» (annealing отжиг; coining - чеканка; drawing - волочение; forging - ковка; injection molding - литье под давлением; quenching - закалка; sintering - спекание; soldering - пайка; stamping - штамповка; tempering - отпуск);

5. «Машина/инструмент/оборудование/» (anvil - наковальня; drop hammer - штамповочный молот; furnace - плавильная печь; grinder - шлифовальный станок; hot chamber - горячая камера; milling machine - фрезерный станок; rolling mill - прокатный стан; shank-type cutter - черенковый резец; torch - горелка; welding gun - сварочный пистолет).

В основе формирования лексических единиц, компонентов анализируемой группы лежат терминологизация, межъязыковые заимствования и морфологический способ. Так, элемент английской общеупотребительной лексики «green», в русском языке представленный значениями «зеленый/свежий/экологически чистый», в области материаловедения трактуется как «необработанный (металл)/незакалённый (сталь)/необожжённый (фарфор)/неспечённый (порошковая прессованная заготовка)/затвердевший (бетон, раствор)/непросушенный (песок)». В терминологическом массиве материаловедения и технологий материалов переосмыслены значения «article» (статья/раздел/артикль/) - «изделие/ деталь»; «bar» (бар) - «прут/стержень»; «bed» (кровать) - «станина»; «China» (Китай) - «фарфор/фарфоровые изделия»; «сure» (лечить/исправлять) - «вулканизировать (резину)/пропаривать (бетон)»; «die» (умирать/затухать/ заканчиваться) - «штамп/матрица/пресс-форма/заготовка»; «dull» (тупой/затупившийся) - «матовый»; «fine» (прекрасный/изысканный) - «мелкозернистый/мелкодисперсный/чистый (серебро)»; «ріg» (поросенок) «болванка (чушка металла)/слиток» [3].

Межъязыковое взаимодействие в контексте рассматриваемой терминосистемы отражено в терминах-заимствованиях английского и русского языков, имеющих интернациональный характер и тождественность смыслового содержания: «caustic cracking» - «каустический крекинг»; «ceramic pigment» - «керамический пигмент»; «cloisonne» - «клуазонне»; «composite» - «композит»; «filigree» - «филигрань»; «hybrid material» - «гибридный материал»; «megaplastic deformation» - «мегапластическая деформация»; «passive metal»- «пассивный металл»; «patina» - «патина»; «polymer» - «полимер» [5].

В терминосистеме «материаловедение и технологии материалов» словосложение, как способ морфологического образования специальных понятий, в английском языке демонстрирует широкие потенции, например: «alloy dressing» - «разделка сплава»; «ball iron» - «кричное железо»; «box casting» - «елочная отливка»; «cake copper» - «штыковая медь»; «cat eyes» - «нерастворённые частицы каучука (в резиновом клее)»; «fish scale» - «чешуйчатость (дефект поверхности)»; «ingot dogs» - «клещи для слитков»; «lead jacket» - «свинцовая оболочка»; «silicon wafer» - «кремневая пластина/вафля»; «tongue-and-groove rolling» - «прокатка в закрытых калибрах». Данные номинации активно эксплуатируют модели метафорического образования терминоэлементов, источниками (донорами) которых являются фауна (cat, dog, fish), одежда (jacket), пища (cake, wafer), предмет повседневного обихода (box), физическое действие человека (dressing), игровой/спортивный инвентарь (ball), орган (eyes, tongue). Как отмечает Т.А. Сытникова, метафорическое терминообразование является вполне закономерным процессом и весьма продуктивным способом именования ранее не называемых понятий, учитывая высокую скорость их появления [4, с. 8]. В русском языке метафорический образ английских терминов сферы материаловедения и технологий материалов раскрывается в менее выразительной форме.

Терминообразовательный потенциал языка определяется терминологической деривацией и терминообразовательными типами [2, с. 24]. Английская терминология исследуемой предметной области, как правило, многокомпонентна и преимущество выстраивается согласно моделям:

1. Noun + Noun (creep recovery - обратная ползучесть; fountain brick - центровой литник);

2. Noun + Noun + Noun (fatigue load limit - предел усталостной нагрузки; zinc phosphate treatment фосфатирование);

3. Adjective + Noun (black silver - хрупкая серебряная руда; cyclic stress - циклическое напряжение);

4. Participle II + Noun (forged stock - кузнечная заготовка; killed heat - раскисленная плавка);

5. Participle II + Noun + Noun (cut stone veneer - облицовка из тёсаного камня; repeated tension test испытание на повторное растяжение).

В процессе исследования также были выделены три модели четырехкомпонентных словосочетаний терминологического характера:

1. Adverb + Adjective + Noun + Noun (extra-low-carbon ferrochrome - безуглеродистый феррохром);

2. Adjective + Noun + Noun + Noun (low alloy carbon steel - низколегированная углеродистая сталь);

3. Noun +Noun + Participle II + Noun (fiber glass reinforced plastics - стеклопласты).

Установлено, что терминообразующим потенциалом в английском и русском языках в большей мере обладают имена существительные и имена прилага- 
тельные. Глагольные термины в английском языке проявляют признаки изолирующего строя с характерным для него конверсивным типом образования глагольных терминов от терминов-существительных [1, с. 39]. В терминосистеме «материаловедение и технологии материалов» данная особенность реализуется в следующих примерах с эквивалентными глагольными вариантами русского языка: «to hammer» - «ковать/чеканить»; «to iron» - «покрывать железом/металлом; править (на правильной машине/прессе)»; «to machine» - «подвергать машинной обработке/обрабатывать на станке»; «to nickel» - «никелировать»; «to sand» - «шлифовать/ зачищать шкуркой»; «to shape» - «придавать форму»; «to steel» - «покрывать сталью/закалять»; «to strain» «деформировать/растягивать»; «to subject» - «подвер- гать (воздействию)»;«to tool» - «обрабатывать резцом (металл); обтесывать (камень)».

Таким образом, основной механизм формирования терминосистемы «материаловедение и технологии материалов» отражается в осмыслении общеупотребительной лексики в техническом контексте, включении общенаучных и узкоспециальных терминологических единиц, межотраслевых терминов (специальных понятий из области физики, химии и металлургии), акцентируя интегративный характер данной предметной области, демонстрируя языковую связностью, целостность, полноту, информативность, тематическую продуктивность, высокую образность, коммуникативную четкостью и контекстуальный характер ее компонентов.

\section{ЛИТЕРАТУРА}

1. Исакова Л.Д. Функционирование глагольных терминов в научных текстах (сопоставительный аспект) / Л.Д. Исакова // Вестник МГЛу. Гуманитарные науки. - 2018. - № 2 (791). - С. 89-98.

2. Карапетьян А.Э. Терминосистема танца в английском и русском языках: лексико-семантический и лингвокультурный аспекты: автореф. дис. ... канд. филол. наук. - Краснодар, 2008. - 30 с.

3. Словарь Multitran [Электронный ресурс]. - Режим доступа: https://www.multitran.com (дата обращения: 15.02.2021).

4. Сытникова Т.А. Англоязычная компьютерная техническая терминосистема как объект лингвокогнитивного исследования: автореф. дис. ... канд. филол. наук. - Владивосток, 2011. - 23 с.

5. Collins Dictionary [Электронный ресурс]. - Режим доступа: https://www.collinsdictionary.com (дата обращения: 15.02.2021).

○ Ступина Татьяна Владимировна (stupina_tv@mail.ru), Филончик Ольга Александровна (oly-fill@yandex.ru), Антолиновская Вера Михайловна (antolinv@mail.ru).

Журнал «Современная наука: актуальные проблемы теории и практики» 